\title{
Butyric Acid and Leucine Induce $\alpha$-Defensin Secretion from Small Intestinal Paneth Cells
}

\author{
Akiko Takakuwa ${ }^{1,2}$, Kiminori Nakamura ${ }^{1,3}$, Mani Kikuchi ${ }^{3}$, Rina Sugimoto ${ }^{1} \oplus$, Shuya Ohira ${ }^{1}$, \\ Yuki Yokoi ${ }^{1}$ (D) and Tokiyoshi Ayabe 1,3,*(D) \\ 1 Department of Cell Biological Science, Graduate School of Life Science, Hokkaido University, Kita-21, \\ Nishi-11, Kita-ku, Sapporo, Hokkaido 001-0021, Japan; takakuwa@tenshi.ac.jp (A.T.); \\ kiminori@sci.hokudai.ac.jp (K.N.); r_sugimoto@eis.hokudai.ac.jp (R.S.); shuyan@eis.hokudai.ac.jp (S.O.); \\ y-yokoi-b-s@eis.hokudai.ac.jp (Y.Y.) \\ 2 Department of Nutrition, Faculty of Nursing and Nutrition, Tenshi College, 3-1-30 Higashi, Kita-13, \\ Higashi-ku, Sapporo Hokkaido 065-0013, Japan \\ 3 Department of Cell Biological Science, Faculty of Advanced Life Science, Hokkaido University, Kita-21, \\ Nishi-11, Kita-ku, Sapporo, Hokkaido 001-0021, Japan; manikikuchi@sci.hokudai.ac.jp \\ * Correspondence: ayabe@sci.hokudai.ac.jp; Tel.: +81-11-706-9049
}

Received: 15 August 2019; Accepted: 13 November 2019; Published: 18 November 2019

check for updates

\begin{abstract}
The intestine not only plays a role in fundamental processes in digestion and nutrient absorption, but it also has a role in eliminating ingested pathogenic bacteria and viruses. Paneth cells, which reside at the base of small intestinal crypts, secrete $\alpha$-defensins and contribute to enteric innate immunity through potent microbicidal activities. However, the relationship between food factors and the innate immune functions of Paneth cells remains unknown. Here, we examined whether short-chain fatty acids and amino acids induce $\alpha$-defensin secretion from Paneth cells in the isolated crypts of small intestine. Butyric acid and leucine elicit $\alpha$-defensin secretion by Paneth cells, which kills Salmonella typhimurium. We further measured Paneth cell secretion in response to butyric acid and leucine using enteroids, a three-dimensional ex vivo culture system of small intestinal epithelial cells. Paneth cells expressed short-chain fatty acid receptors, Gpr41, Gpr43, and Gpr109a mRNAs for butyric acid, and amino acid transporter Slc7a8 mRNA for leucine. Antagonists of Gpr41 and Slc7a8 inhibited granule secretion by Paneth cells, indicating that these receptor and transporter on Paneth cells induce granule secretion. Our findings suggest that Paneth cells may contribute to intestinal homeostasis by secreting $\alpha$-defensins in response to certain nutrients or metabolites.
\end{abstract}

Keywords: Paneth cell; $\alpha$-defensin; short-chain fatty acid; amino acid; innate immunity; intestinal microbiota; butyric acid; leucine; Gpr41; Slc7a8

\section{Introduction}

Paneth cells, one of the small intestinal epithelial cell lineages, secrete the antimicrobial peptide $\alpha$-defensin and contribute to enteric innate immunity through microbicidal activities [1-3]. It has been reported that mouse $\alpha$-defensin, cryptdin, elicits specific bactericidal activities, i.e., potent killing of pathogenic bacteria, with a lesser response against commensals [4]. Additionally, the small intestinal microbiota changes in response to a difference in $\alpha$-defensin levels [5]. Secreted $\alpha$-defensin influences the colonic microbiota based on a previous report, which showed that $\alpha$-defensin was recovered from the colonic lumen and feces [6,7]. The human intestine harbors over $1 \times 10^{14}$ diverse bacteria [8]. The intestinal microbiota composition and metabolites affect host immunity; therefore, a normal intestinal microbiota is important for intestinal homeostasis.

One layer of small intestinal epithelial cells constituting the crypts and villi is constantly exposed to stimulation from the intestinal microbiota and separates the intestinal tissue that is "inside" from 
the intestinal tract cavity, which is "outside" of the layer of small intestinal epithelial cells. It has been reported that abnormalities in $\alpha$-defensin secretion by Paneth cells are involved in the onset and pathology of certain diseases, such as inflammatory bowel diseases, obesity, or graft-versus-host disease (GVHD) [9]. A decrease in the number of Paneth cells and morphological Paneth cell abnormalities lead to dysbiosis, the disruption of the intestinal microbiota, via a reduction or dysfunction in $\alpha$-defensin secretion, resulting in the onset of certain diseases. Therefore, $\alpha$-defensin secreted by Paneth cells maintains intestinal homeostasis, possibly by regulating the intestinal microbiota, which contributes to maintaining health and preventing disease [10].

Previously, Paneth cells were shown to secrete $\alpha$-defensin in response to stimuli from cholinergic agents and bacteria, including live and dead bacteria, or their antigens, including lipopolysaccharide (LPS) [1]. We previously reported that $\alpha$-defensin, secreted in the lumen of the mouse intestine, is highest in the ileum, where the number of intestinal bacteria increases dramatically, as well as in the duodenum and jejunum, where food digestion and absorption occur [11]. Additionally, a correlation between Paneth cell number and diet has been reported; the number of Paneth cells in the duodenum and jejunum decreases following excessive calorie intake (diet rich in carbohydrate and fat) [12]. Paneth cells are known to form a stem cell niche [13] and enhance stem cell function in response to calorie limitations [14,15]. Thus, Paneth cells may respond to the intestinal environment, such as dietary factors or the absorption process. However, it is not known whether $\alpha$-defensin secretion by Paneth cells is induced by nutrients.

This study was conducted to clarify whether short-chain fatty acids (SCFAs) and amino acids, both of which are nutrient sources in the intestinal environment, induce $\alpha$-defensin secretion by Paneth cells. Since the SCFAs and amino acids also have signal-transducing roles [16,17], we analyzed whether these nutrients trigger Paneth cell secretion. Here, we show that butyric acid and leucine induce $\alpha$-defensin secretion from Paneth cells. We evaluated the effect of SCFA and amino acid on the induction of Paneth cell secretion using isolated crypts of the mouse small intestine. Additionally, we showed that Paneth cells express receptors and transporter that recognize butyric acid and leucine, suggesting that Paneth cells secrete $\alpha$-defensin via these receptors and transporter. Using microinjection methods on enteroids [18], granule secretion in response to butyric acid and leucine was evaluated. Further, antagonists of Gpr41 and Slc7a8 inhibited butyric acid-induced and leucine-induced granule secretions from Paneth cells, respectively, suggesting involvement of these receptors and the transporter in Paneth cell secretion. This study suggests a potential new role for nutrients as intestinal environmental factors that maintain intestinal homeostasis by stimulating the secretion of $\alpha$-defensin by Paneth cells.

\section{Materials and Methods}

\subsection{Animals}

Crlj: CD1 (ICR) mice were purchased from Charles River Japan (Kanagawa, Japan). All animal experiments were approved by the Committee of Animal Experimentation at Hokkaido University.

\subsection{Reagents}

Propionic acid (PA), butyric acid (BA), L-glycine (Gly), L-alanine (Ala), L-serine (Ser), L-threonine (Thr), L-cysteine (Cys), L-methionine (Met), L-valine (Val), L-leucine (Leu), L-isoleucine (Ile), L-phenylalanine (Phe), L-tryptophan (Trp), L-aspartic acid (Asp), L-glutamic acid (Glu), L-asparagine (Asn), L-glutamine (Glu), L-histidine (His), L-asparagine monohydrate (Arg), L-tyrosine (Tyr), and L-ascorbic acid were purchased from FUJIFILM Wako (Osaka, Japan). Acetic acid (AA), L-lysine (Lys), and sodium butyrate were purchased from Nacalai Tesque (Kyoto, Japan), and proline (Pro) was purchased from Sigma-Aldrich (St. Louis, MO, USA). All chemicals were of analytical grade. 


\subsection{Crypt Isolation}

2.3.1. Crypt Isolation for Sandwich Enzyme-Linked Immunosorbent Assay (ELISA) and Bactericidal Assay

Crypts were isolated from the small intestine, as previously described [1]. The small intestine lumen of adult mice was rinsed with ice-cold water, yielding the ileum segments. The segments were everted and shaken in cold $\mathrm{Ca}^{2+}$ - and $\mathrm{Mg}^{2+}$-free Hank's balanced salt solution (HBSS) containing $30 \mathrm{mM}$ EDTA to detach the crypts. Villi and crypts detached for 7-min intervals were deposited by centrifugation at $700 \times g$ for $5 \mathrm{~min}$ at $4{ }^{\circ} \mathrm{C}$ and resuspended in phosphate-buffered saline (PBS). For experiments using $>10,000$ crypts, the numbers were estimated by hemocytometry.

\subsubsection{Crypt Isolation for Quantitative Polymerase Chain Reaction (qPCR) and Enteroid Culture}

For crypt isolation, mouse small intestine was flushed with cold $\mathrm{Ca}^{2+}$ - and $\mathrm{Mg}^{2+}$-free PBS and cut open lengthwise in $\sim 10 \mathrm{~cm}$ long pieces. The villi were scraped off using a scalpel blade and washed with cold PBS. The tissue fragments were incubated in $30 \mathrm{mM}$ EDTA with HBSS for $10 \mathrm{~min}$ at $25^{\circ} \mathrm{C}$. The solution was removed, and the tissue was shaken vigorously for $\sim 300$ times in fresh HBSS. Intact tissue was discarded, and dissociated crypts were pelleted by centrifugation at $440 \times g$ for $4 \mathrm{~min}$ at $4{ }^{\circ} \mathrm{C}$.

\subsection{Stimulation and Collection of Paneth Cell Secretions}

The crypt fractions obtained in Section 2.3.1 were incubated at $37{ }^{\circ} \mathrm{C}$ for $30 \mathrm{~min}$ to stimulate secretion of a-defensin from Paneth cells by adjusting the final concentration to $100 \mu \mathrm{M} \mathrm{SCFAs}$ or $1 \mu \mathrm{M}$ amino acids and PBS control. Supernatants were collected by centrifugation at $700 \times g$ for 5 min at $4{ }^{\circ} \mathrm{C}$. Supernatants were adjusted to $30 \%$ acetic acid, and proteins were extracted using a 1000 Da dialysis membrane (Spectrum Laboratories, Rancho Dominguez, CA, USA) overnight at $4{ }^{\circ} \mathrm{C}$. The solution after the dialysis was lyophilized and stored at $-80^{\circ} \mathrm{C}$ until use.

\subsection{Sandwich ELISA}

The materials obtained in Section 2.4 were dissolved in $200 \mu \mathrm{L}$ of PBS, and cryptdin-1 (Crp1), which is a major isoform of mouse $\alpha$-defensin, was measured by sandwich ELISA as previously described [11]. Microtiter plate wells were coated overnight at $4{ }^{\circ} \mathrm{C}$ with $100 \mu \mathrm{L}$ of the capture antibody (77-R5) at a concentration of $1 \mu \mathrm{g} / \mathrm{mL}$ in $50 \mathrm{mM}$ sodium carbonate-bicarbonate buffer ( $\mathrm{pH}$ 9.6). The plate was then washed with PBS-T and blocked at $25{ }^{\circ} \mathrm{C}$ for $1 \mathrm{~h}$ with $200 \mu \mathrm{L}$ of $25 \%$ Block Ace (DS Pharma Biomedical, Osaka, Japan). Next, $100 \mu \mathrm{L}$ of Crp1 or samples were added to the wells and incubated at $25^{\circ} \mathrm{C}$ for $2 \mathrm{~h}$. After washing in PBS-T, $100 \mu \mathrm{L}$ biotinylated detection antibody (77-R20, $0.5 \mu \mathrm{g} / \mathrm{mL}$ ) was added at $25^{\circ} \mathrm{C}$ for $1 \mathrm{~h}$. Subsequently, the wells were incubated with $100 \mu \mathrm{L}$ of streptavidin-horseradish peroxidase conjugate (GE Healthcare, Little Chalfont, UK) in a 1:5000 dilution at $25^{\circ} \mathrm{C}$ for $1 \mathrm{~h}$. After the final wash, $100 \mu \mathrm{L}$ of TMB chromogen substrate buffer was added and incubated at $25^{\circ} \mathrm{C}$ for $30 \mathrm{~min}$. The reaction was stopped by adding $100 \mu \mathrm{L}$ of $0.6 \mathrm{~N} \mathrm{H}_{2} \mathrm{SO}_{4}$, and absorbance values were determined at $450 \mathrm{~nm}$ using a microplate reader (Multiscan FC, Thermo Fisher Scientific, Waltham, MA, USA).

\subsection{Bactericidal Assay}

The bactericidal assay was performed as previously described [1]. Secretions collected from crypts exposed to PBS, $100 \mu \mathrm{M}$ butyric acid, and $1 \mu \mathrm{M}$ leucine obtained in Section 2.4 were analyzed for bactericidal activity against $1 \times 10^{3}$ colony-forming units of Salmonella typhimurium PhoP- (S. typhimurium) incubated at $37^{\circ} \mathrm{C}$ for $1 \mathrm{~h}$. Surviving colonies were quantified by evaluating their growth on semi-solid media at $37^{\circ} \mathrm{C}$ overnight. Bacterial survival rates were determined from surviving colonies relative to the PBS control. 


\section{7. qPCR Analysis of Receptor and Transporter Gene Expression}

The small intestinal crypts were resuspended in HBSS $300 \mathrm{U} / \mathrm{mL}$ collagenase (Sigma-Aldrich), $10 \mu \mathrm{M}$ Y-27632 (Sigma-Aldrich), and $1 \mathrm{mM} \mathrm{N}$-acetylcysteine (Sigma-Aldrich) at $37^{\circ} \mathrm{C}$, and shaken at $180 \mathrm{rpm}$ for $5 \mathrm{~min}$ on a horizontal shaker (TAITEC, Kyoto, Japan). Next, $50 \mu \mathrm{g} / \mu \mathrm{L}$ DNase I (Roche, Basel, Switzerland) was added and the sample was mixed by pipetting. Cells were pelleted at $500 \times g$ for $5 \mathrm{~min}$ at $4{ }^{\circ} \mathrm{C}$ and resuspended in washing buffer (DMEM/F12, $10 \mu \mathrm{M}$ Y-27632, $1 \mathrm{mM} \mathrm{N}$-acetylcysteine). Cells were then passed through a 40- $\mu \mathrm{m}$ cell strainer (BD Falcon, Franklin Lakes, NJ, USA) and washed with washing buffer. For Paneth cell enrichment, Paneth cell granules were stained with $10 \mu \mathrm{M}$ Zinpyr-1 (Santa Cruz Biotechnology, Dallas, TX, USA) in washing buffer at $37^{\circ} \mathrm{C}$ for $10 \mathrm{~min}$ and washed in washing buffer. After Zinpyr-1 staining, the cells were passed through a $35-\mu \mathrm{m}$-pore-size filter Cell Strainer cap (BD Falcon) prior to cell sorting. Zinpyr-1+ cells were sorted by flow cytometry (JSAN; Bay Bioscience, Kobe, Japan). Single cells were gated by forward scatter and side scatter. Sorted cells were collected in washing buffer.

For Paneth cell isolation, Paneth cells were identified as Zinpyr-1 ${ }^{+}$granular cells in PBS on a poly (HEMA)-coated glass slide under a confocal microscope (A1; Nikon, Tokyo, Japan). Each Paneth cell was aspirated individually using a 50- $\mu \mathrm{m}$ glass micropipette (1-GT50S-5; NEPAGENE, Ichikawa, Japan) with micromanipulators (MN-4, MMO-202ND; NARISHIGE, Tokyo, Japan) and an electronic pipette (PicoPipet; NEPAGENE), and placed into $4 \mu \mathrm{L}$ of lysis buffer from SingleShotTM Cell Lysis Kit (Bio-Rad Laboratories, Hercules, CA, USA) in the flat optical caps of Vari-Strip ${ }^{\mathrm{TM}}$ low profile 8 strip tubes (NIPPON Genetics, Tokyo, Japan). Each cell lysate containing 50 Paneth cells was placed in a 0.2-mL PCR tube (NIPPON Genetics).

After cell isolation, the cell lysates were incubated at $25^{\circ} \mathrm{C}$ for $10 \mathrm{~min}$ and boiled at $75{ }^{\circ} \mathrm{C}$ for 5 min. cDNA was synthesized with the iScriptTM Advanced cDNA synthesis kit for RT-qPCR (Bio-Rad Laboratories) using $10 \mu \mathrm{L}$ of a reaction mixture containing $4 \mu \mathrm{L}$ of cell lysate, $2 \mu \mathrm{L}$ of $5 \times$ iScript Advanced reaction mix, and $0.5 \mu \mathrm{L}$ of iScript Advanced reverse transcriptase. The complete reaction was cycled at $42{ }^{\circ} \mathrm{C}$ for $30 \mathrm{~min}$ and at $85^{\circ} \mathrm{C}$ for $5 \mathrm{~min}$. Thermal cycling was performed using a Veriti Thermal cycler (Thermo Fisher Scientific). PCR primers are listed in Supplementary Table S1. The relative mRNA levels were calculated according to the $2 \Delta \mathrm{Ct}$ method, using $\beta$-actin as a reference.

\subsection{Western Blot}

Crypts were homogenized in T-PER Tissue Protein Extraction Reagent (Thermo Fisher Scientific) in the presence of a protease inhibitor cocktail (Nacalai Tesque) using a Nippi Biomasher (Nippi, Tokyo, Japan) for $1 \mathrm{~h}$ at $4{ }^{\circ} \mathrm{C}$. Homogenized crypts were centrifuged at 20,000 $\mathrm{g}$ for $30 \mathrm{~min}$ to obtain supernatants. Protein concentrations in the supernatants were measured using a BCA protein assay kit (Thermo Fisher Scientific). Samples, including $10 \mathrm{mg}$ of protein and 25 or $50 \mathrm{ng}$ of mouse kidney lysate (positive control), were separated on an SDS-PAGE, following which proteins were transferred to nitrocellulose membranes. The membrane was blocked with StabilGuard (SurModics, Eden Prairie, MN, USA) for $1 \mathrm{~h}$ at $25^{\circ} \mathrm{C}$ and then incubated at $4{ }^{\circ} \mathrm{C}$ overnight with $1 \mu \mathrm{g} / \mathrm{mL}$ anti-FFAR3/GPR41 (ab236654; Abcam, Cambridge, UK), anti-FFAR2/GPR43 (ABC299; Merck Millipore, Darmstadt, Germany), and anti-LAT2/Slc7a8 antibody (ab75610; Abcam) antibodies. After the membranes were washed, they were incubated for $1 \mathrm{~h}$ at $25^{\circ} \mathrm{C}$ with goat anti-rat IgG-HRP (Imgenex, San Diego, CA, USA). After another wash, the proteins were detected using a chemiluminescent substrate (Chemi-Lumi One, Nacalai Tesque).

\subsection{Immunofluorescence Staining}

The ileum tissue from the CD1 (ICR) mice were fixed in 10\% neutralized buffered formalin, embedded in paraffin, and placed on poly-L-lysine-pretreated slides. For immunofluorescent staining, after deparaffinization and rehydration, the antigens were retrieved in an autoclave at $105{ }^{\circ} \mathrm{C}$ for $20 \mathrm{~min}$ with Tris-EDTA (ethylenediaminetetraacetic acid) buffer (pH 9.0). After the antigen 
retrieval, nonspecific binding was blocked with 5\% goat serum. Primary antibody reaction was performed with $1 \mu \mathrm{g} / \mathrm{mL}$ rat monoclonal anti-cryprdin-1 (clone: 77-R63, produced by our laboratory), $25 \mu \mathrm{g} / \mathrm{mL}$ anti-FFAR3/GPR41 (Abcam), $10 \mu \mathrm{g} / \mathrm{mL}$ anti-FFAR2/GPR43 (Merck Millipore), and $50 \mu \mathrm{g} / \mathrm{mL}$ anti-LAT2/Slc7a8 antibody (Abcam) diluted by PBS at $4{ }^{\circ} \mathrm{C}$ overnight. After rinsing in PBS, tissue sections were incubated with Alexa Fluor 488 goat anti-Rabbit IgG and Alexa Fluor 594 goat anti-Rat IgG (dilution 1:400, Thermo Fisher Scientific) diluted by PBS. Tissue sections were also counterstained with $5 \mu \mathrm{g} / \mathrm{mL}$ staining 4',6-diamidino-2-phenylindole (DAPI, Thermo Fisher Scientific) for $5 \mathrm{~min}$ at $25{ }^{\circ} \mathrm{C}$ to visualize nuclei and were mounted with Aqua Poly/Mount (Polysciences, Warrington, PA, USA). Pictures were taken using a confocal microscope (A1, Nikon).

\subsection{Quantification of Paneth Cell Granule Secretion in Enteroids}

Enteroid culture was performed as previously described [18]. The pellets, as obtained in Section 2.3.2, were resuspended in HBSS supplemented with $10 \mu \mathrm{M}$ Y-27632 (Sigma-Aldrich), the crypts were counted, and a fraction of $>80 \%$ crypt purity was used. The fraction was centrifugated at $400 \times g$ for $4 \mathrm{~min}$ at $4{ }^{\circ} \mathrm{C}$, and 150 crypts were resuspended in $30 \mu \mathrm{L}$ of Matrigel (Corning, Inc., Corning, NY, USA), followed by plating in 48-well plates (Thermo Fisher Scientific). After Matrigel polymerization, $250 \mu \mathrm{L}$ of enteroid culture medium (Advanced DMEM/F12 supplemented with penicillin/streptomycin, $10 \mathrm{mM}$ HEPES, $1 \times$ GlutaMAX, 1× N2, 1× B27 (all from Thermo Fisher Scientific), and $1 \mu \mathrm{M} \mathrm{N}$-acetylcysteine containing growth factors $50 \mathrm{ng} / \mathrm{mL}$ EGF (PeproTech, Rocky Hill, NJ, USA), 50 ng/mL HA-R-Spondin1-Fc (produced using Cultrex ${ }^{\circledR}$ HA-R-Spondin1-Fc 293T Cells, Trevigen, Gaithersburg, MD, USA; \#3710-001-01), and 100 ng/mL Noggin (PeproTech) were overlaid. The culture medium was changed every other day.

At day 5-7 of culture, enteroids were harvested by dissolving Matrigel with cold Advanced DMEM/F12 and transferred onto a Cell Imaging Dish (Eppendorf, Hamburg, Germany) at 150 enteroids/dish. The dish was kept on ice for $5 \mathrm{~min}$ to allow the enteroids to settle on the bottom of the dish. After Matrigel polymerization, enteroid culture media pre-warmed to $37^{\circ} \mathrm{C}$ was added to the dish $30 \mathrm{~min}$ before microinjection. Binding inhibition assay (butyrate binding to Gpr41) was performed by adding culture media containing $1 \mathrm{mM}$ beta-hydroxybutyrate (BHB) (Sigma-Aldrich), an antagonist to Gpr41 [19], to the dish $30 \mathrm{~min}$ before microinjection. For L-leucine and L-threonine injection, culture media containing Advanced DMEM/F12, which lacks individual essential amino acids (leucine or threonine, respectively) (Research Institute for the Functional Peptides, Yamagata, Japan), were added respectively, and the enteroids were microinjected with these compounds (nutrients or antagonist) after $12 \mathrm{~h}$ of culture. For the L-leucine transporter Slc7a8 inhibition assay, culture media (lacking L-leucine) containing $6 \mathrm{mM}$ 2-amino-2-norbornane-carboxylic acid (BCH) (R \& D system, Minneapolis, MN, USA), an antagonist of Slc7a8 [20], was added to the dish for $12 \mathrm{~h}$ before microinjection.

Microinjection was performed while scanning the enteroid at 15 frames/s by confocal microscopy in a microscope cage incubator $\left(37^{\circ} \mathrm{C}, 5 \% \mathrm{CO}_{2}\right.$, Tokken, Kashiwa, Japan). The needle (Femtotips, Eppendorf) was inserted into the enteroid by using Coarse and Fine Three-axis Oil Hydraulic Micromanipulator and One-axis Oil Hydraulic Micromanipulator (MN-4, MMO-202ND, MMO-220A, NARISHIGE), and reagents were introduced into the enteroid lumen using a Pneumatic Microinjector (IM-11-2, NARISHIGE) at a final concentration of $50 \mathrm{mM}$ sodium butyrate, $1 \mu \mathrm{M}$ L-leucine, and $1 \mu \mathrm{M}$ L-threonine. For the Gpr41 inhibition assay, sodium butyrate and BHB were co-injected at a final concentration of 50 and $1 \mathrm{mM}$, respectively. For the Slc7a8 inhibition assay, L-leucine and $\mathrm{BCH}$ were co-injected at a final concentration of 1 and $6 \mathrm{mM}$, respectively.

Differential interference contrast time-lapse imaging was performed using a confocal microscope (A1, Nikon) equipped with a 0.95 NA objective lens (CFI Apo LWD 20X WI $\lambda S$, Nikon) and a resonant scanner at 15 frames/s from the start of injection to $30 \mathrm{~min}$ after the introduction of reagents. To quantify Paneth cell granule secretion, the number of granules secreted for $30 \mathrm{~min}$ after the introduction of reagents was counted by observing the images displayed by the frame-by-frame playback with an 
image analysis software, NIS-Elements AR (Nikon). For sodium butyrate, L-leucine, and L-threonine, microinjection was performed on five enteroids, and the number of secreted granules in one experiment represents the total number of secreted granules in five microinjections. The experiment was repeated three times. For the inhibition assay, microinjection was performed on three enteroids, and the experiment was repeated four times.

\subsection{Statistical Analysis}

All statistical computations were performed using GraphPad Prism 6.07 software (GraphPad, Inc., San Diego, CA, USA). Data comparing two groups were analyzed by the two-tailed unpaired Student's $t$-test. Data comparing several treatments were analyzed by one-way analysis of variance, followed by Tukey's post hoc test for multiple comparisons and the Kruskal-Wallis test. Differences between groups were considered significant if $p$-values were $<0.05$.

\section{Results}

\subsection{Paneth Cells Secrete $\alpha$-Defensin in Response to Butyric Acid among SCFAs}

First, we examined whether three kinds of SCFAs, acetic acid, propionic acid, and butyric acid, induce $\alpha$-defensin secretion from Paneth cells by measuring the amount of Crp1 secretion using sandwich ELISA. Butyric acid significantly induced Crp1 secretion in Paneth cells compared to in the PBS control (Figure 1c, $46.5 \pm 8.4 \mathrm{ng} / \mathrm{mL}, p<0.05$ ). In contrast, no significant secretion was observed with either acetic acid or propionic acid compared to with PBS (Figure 1a, $22.7 \pm 3.9 \mathrm{ng} / \mathrm{mL}$, Figure 1b, $22.3 \pm 3.2 \mathrm{ng} / \mathrm{mL}$, respectively). Ascorbic acid $(100 \mu \mathrm{M})$, a nutrient tested for comparison with SCFAs, did not induce Crp1 secretion (Supplementary Figure S1). Butyric acid further showed a tendency to induce $\alpha$-defensin secretion in a concentration-dependent manner when the dose of butyric acid was changed from 1 to $100 \mu \mathrm{M}$ (Supplementary Figure S2a). Furthermore, the collected Paneth cell secretions induced by butyric acid elicited potent bactericidal activities against $S$. typhimurium in the bactericidal assay, confirming this as the function of the secreted $\alpha$-defensin (Figure 1d). Among the SCFAs tested, butyric acid induced $\alpha$-defensin secretion from Paneth cells.

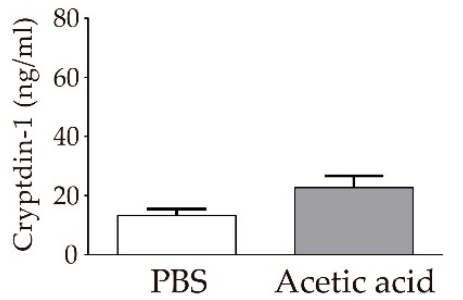

(a)

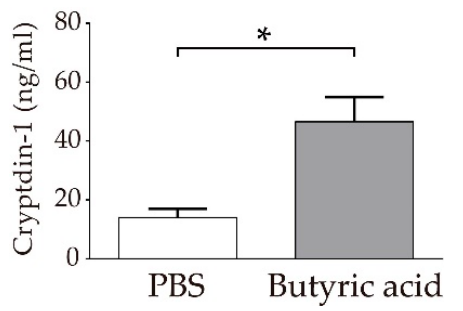

(c)

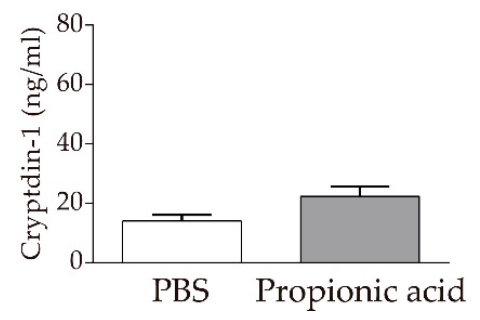

(b)

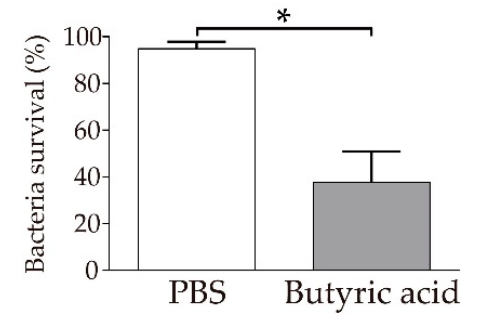

(d)

Figure 1. Induction of Cryptdin-1 (Crp1) secretion from Paneth cells by short-chain fatty acids using isolated crypts of the mouse small intestine: Induction of Crp1 secretion by Paneth cells in response to $100 \mu \mathrm{M}$ (a) Acetic acid, (b) propionic acid, and (c) butyric acid. Data are expressed as the means \pm SEM $(n=5) .{ }^{*} p<0.05$ by Student's $t$-test. (d) Bactericidal activities of Paneth cell secretions stimulated by butyric acid and PBS control against $S$. typhimurium. Data are expressed as the means \pm SEM $(n=3)$. * $p<0.05$ by Student's $t$-test. 


\subsection{Paneth Cells Secrete $\alpha$-Defensin in Response to Leucine among 20 Amino Acids}

Next, Crp1 secretion-inducing activities from Paneth cells were examined for all 20 amino acids. Of the 20 amino acids, leucine significantly induced Crp1 secretion compared to PBS (Figure 2a). In contrast, the remaining 19 amino acids examined did not induce Crp1 secretion. When the secretion induction activities of leucine were tested in $100 \mathrm{nM}$ to $10 \mu \mathrm{M}$, no significant difference was observed at any of the doses despite the significant secretion induced in Paneth cells by leucine (Supplementary Figure S2b). In the bactericidal assay, the secretions collected from Paneth cells induced by leucine showed potent bactericidal activities against $S$. typhimurium (Figure $2 b$ ).

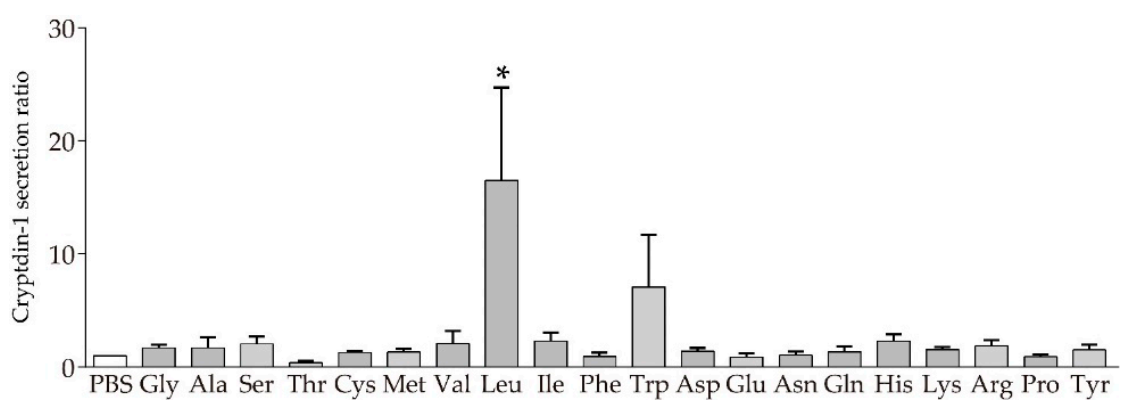

(a)

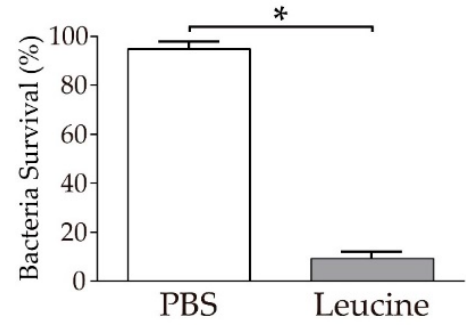

(b)

Figure 2. Induction of Crp1 secretion from Paneth cells by amino acids using isolated crypts of the mouse small intestine: (a) Induction of Crp1 secretion by Paneth cells in response to $1 \mu \mathrm{M}$ amino acids. The results are shown as a relative ratio of Crp1 concentration compared to PBS. Data are expressed as the means \pm SEM $(n=3-6) .{ }^{*} p<0.05$ by Tukey's multiple comparisons test. (b) Bactericidal activities of Paneth cell secretion stimulated by leucine and PBS control against $S$. typhimurium. Data are expressed as the means $\pm \operatorname{SEM}(n=3) .{ }^{*} p<0.05$ by Student's $t$-test.

\subsection{Paneth Cells Express Genes and Proteins for Butyric Acid Receptors and Amino Acid Transporters}

Secretion from Paneth cells was induced by limited components, i.e., butyric acid and leucine from among the SCFAs and amino acids, respectively. As such, further analysis of whether Paneth cells express receptors and transporter that recognize butyric acid and leucine was carried out using highly purified Paneth cells. The expression of the SCFA receptor G protein-coupled receptor (GPCR), amino acid transporter solute carrier (SLC) family, and $\mathrm{Ca}^{2+}$-sensing receptor (CaSR) in highly purified Paneth cells was quantified by real-time PCR (Figure 3a). Paneth cells were found to express Gpr41, Gpr43, and Gpr109a genes, which are SCFA receptors. Paneth cells also expressed Slc7a8 (L-type amino acid transporter-2: LAT-2) using a neutral amino acid other than proline as a substrate. These results showed that Paneth cells express Gpr41, Gpr43, and Gpr109a, which recognize SCFAs, and Slc7a8, which is an amino acid transporter, and further suggest that Paneth cells secrete $\alpha$-defensin by recognizing butyric acid and leucine via these receptors and transporters. Western blots were performed for Gpr41 (FFAR3), Gpr43 (FFAR2), and Slc7a8 whose mRNA expression was observed by qRT-PCR (Figure 3a). Bands with the molecular weight of 39 kDa for Gpr41, 47 kDa for Gpr43, and $58 \mathrm{kDa}$ for Slc7a8 were shown, and the expression of these proteins was confirmed (Figure 3b). Furthermore, immunohistochemical analysis revealed Paneth cells express Gpr41, Gpr43, and Slc7a8 in the mouse ileum (Figure 3c). 


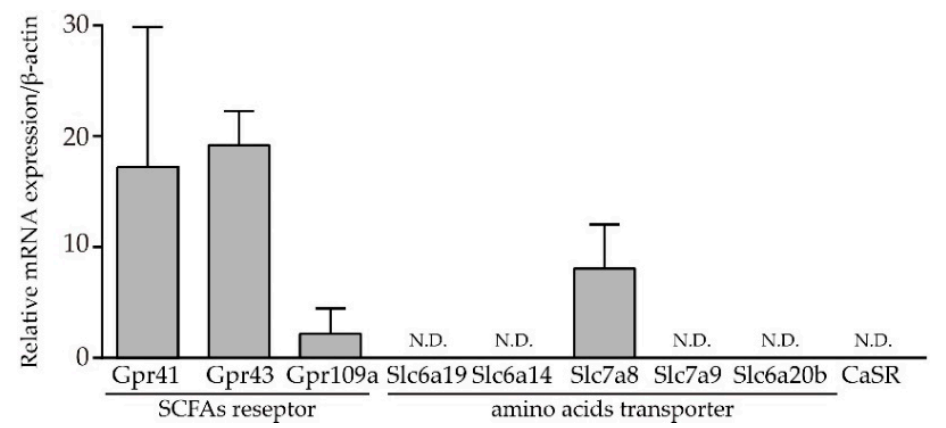

(a)
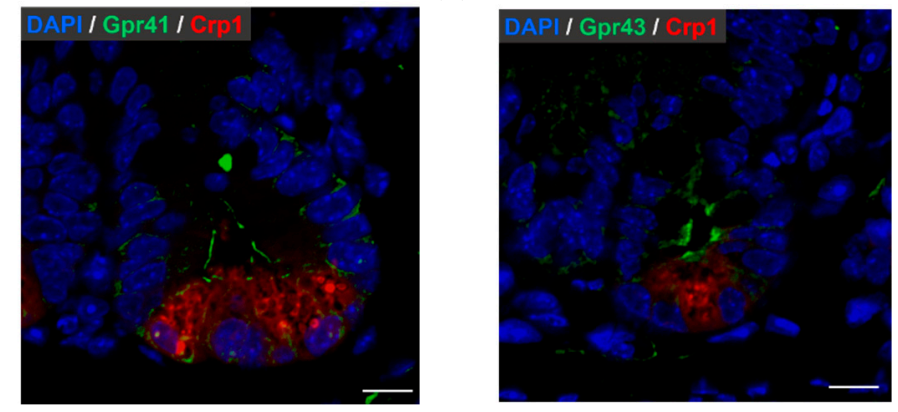

(b)

(c)

Figure 3. Expression of receptors and transporters recognizing short-chain fatty acids or amino acids in Paneth cells: (a) Relative expression of mRNA is shown by the $2 \Delta \mathrm{Ct}$ method as the means $\pm \mathrm{SEM}(n=3)$. (b) Western blot analysis of Gpr41, Gpr43, and Slc7a8 protein expression. Proteins were extracted from crypts of the mouse ileum and kidney. (c) Immunofluorescence staining of Gpr41, Gpr43, and Slc7a8 with Crp1 and 4',6-diamidino-2-phenylindole (DAPI) in the mouse ileum. Scale bar: $10 \mu \mathrm{m}$.

\subsection{Butyric Acid and Leucine Induce Crp1 Secretion in Enteroids}

Finally, to confirm the results obtained with isolated small intestinal crypts, we further tested the stimulatory effect of butyric acid and leucine on the secretion of Paneth cell granules containing a-defensins using enteroids, which are three-dimensional cultures of small intestinal epithelial cells. Secretions were quantitatively analyzed by administering butyric acid or leucine, as well as threonine, which did not induce $\alpha$-defensin secretion, compared to PBS as a control, by using the microinjection method into the lumen of enteroids (Supplementary Figure S3). We observed a significant Paneth cell granule secretion by butyric acid compared to the PBS control (Figure 4a). Leucine also significantly induced granule secretion in enteroid compared to the PBS control and threonine treatment (Figure 4b). These results reproduced and confirmed the results obtained with the isolated crypts. Furthermore, it was confirmed by using enteroids that BHB, which is an antagonist of Gpr41, significantly inhibited Paneth cell granule secretion induced by butyric acid (Figure 4c). An antagonist of Slc7a8, BCH, also inhibited leucine-induced granule secretion (Figure $4 \mathrm{~d}$ ). Moreover, butyric acid and leucine did not induce granule secretion from the basolateral side of Paneth cells in enteroid (Supplementary Methods and Supplementary Figure S4). Taken together, induction of Crp1 secretion by butyric acid and leucine resulted only through the apical stimulation of Paneth cells from the luminal side. 


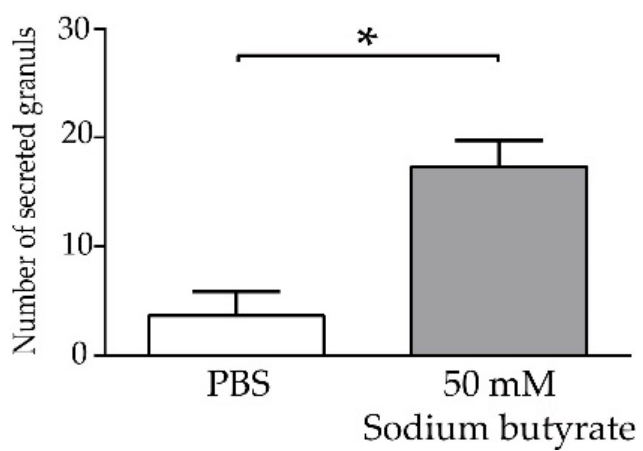

(a)

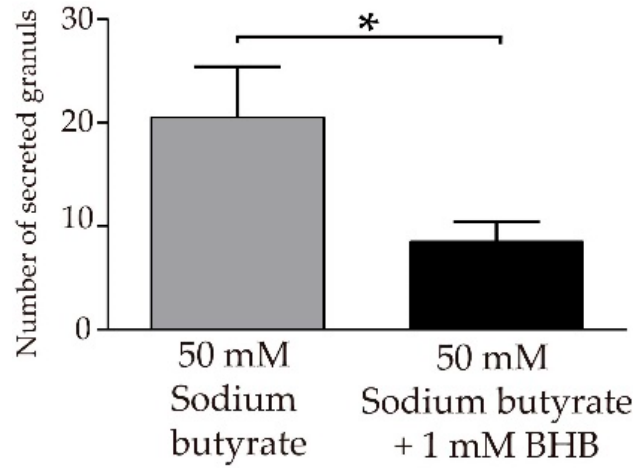

(c)

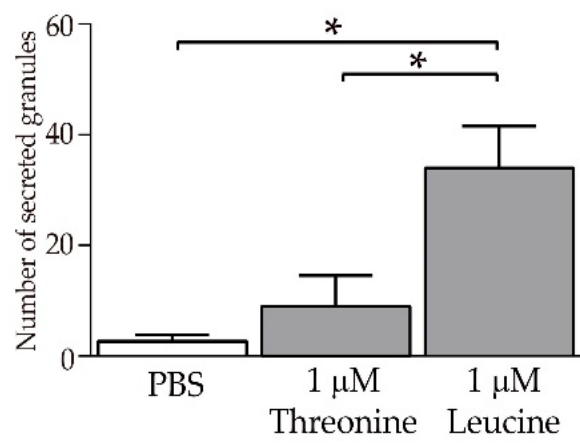

(b)

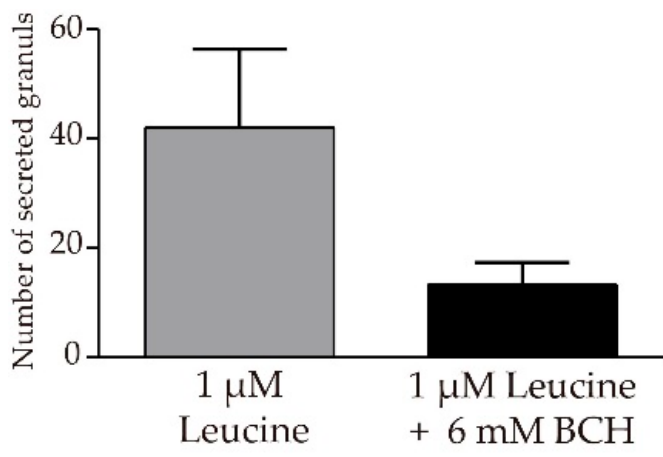

(d)

Figure 4. Quantification of secreted Paneth cell granules in response to butyric acid and leucine: (a) Enteroids at days 5 to 7 were injected with sodium butyrate (right bar, 17.3 \pm 4.2 ) or PBS (left bar, $3.7 \pm 3.8)$. Secreted granules were counted for $30 \mathrm{~min}$ after injection of reagents. Data are expressed as the total number of secreted granules from five Paneth cells \pm SEM $(n=3) .{ }^{*} p<0.05$ by Student's $t$-test. (b) Secreted granules after the introduction of L-threonine (middle bar, 9.0 \pm 9.6) and L-leucine (right bar, $34.0 \pm 13.1$ ) were compared to that after PBS (left bar, $2.7 \pm 2.1$ ). Data are expressed as the total number of secreted granules from five Paneth cells $\pm \operatorname{SEM}(n=3)$. ${ }^{*} p<0.05$ by Tukey's multiple comparisons test. (c) For the Gpr41 inhibition assay, sodium butyrate $(50 \mathrm{mM})$ and beta-hydroxybutyrate (BHB) $(1 \mathrm{mM})$ were co-injected. BHB significantly inhibited butyrate granules secretion. (d) For the Slc7a8 inhibition assay, L-leucine (1 $\mathrm{mM}$ leucine) and 2-amino-2-norbornane-carboxylic acid (BCH) $(6 \mathrm{mM})$ were co-injected. $\mathrm{BCH}$ showed a tendency to inhibit granule secretion induced by leucine.

\section{Discussion}

This study revealed that Paneth cells recognize not only bacteria but also butyric acid and leucine and that they secrete $\alpha$-defensin in response to microbial metabolites or nutrients. Furthermore, the secretions induced by butyric acid and leucine elicit bactericidal activities against pathogenic bacteria, suggesting that butyric acid and leucine as microbial metabolites or nutrients contribute to the maintenance of intestinal homeostasis by inducing $\alpha$-defensin secretion from Paneth cells.

SCFAs are carboxylic acids with six or fewer carbon atoms, comprised of acetic acid, propionic acid, and butyric acid. These molecules are known to be the main metabolites produced by the intestinal microbiota from substrates, such as resistant indigestible polysaccharides derived from the diet, as well as dairy products and fermented foods [21]. SCFAs, produced by the intestinal microbiota, act as host energy sources and as signaling molecules via GPCR [22,23]. Using ligands, GPR41 (FFAR3), GPR43 (FFAR2), and GPR109a (HCA2) were identified as GPCRs for SCFAs [19,24,25]. Energy metabolism and inflammation are controlled by SCFAs via these GPCRs [26,27]. Among them, butyric acid was shown to act as an energy source for intestinal epithelial cells and activate immune functions [28,29]. It was reported that butyric acid activates Forkhead box P3 (Foxp3) transcription via histone deacetylase inhibition in the colon and induces the differentiation of naïve $\mathrm{T}$ cells into regulatory $\mathrm{T}$ cells [30]. Regarding the relationship between Paneth cells and butyric acid, it was reported that the Paneth 
cell number, HD5 mRNA and lysozyme mRNA expression, were decreased in an amyotrophic lateral sclerosis mouse model, and were recovered by administration of $2 \%$ butyric acid in the drinking water to the same levels as those in wild-type mice following [31]. Additionally, butyric acid increases the HD5 gene promoter activities [32]. This study indicates that butyric acid induces $\alpha$-defensin secretion from Paneth cells, further suggesting the previously unknown enteric innate immune functions of butyric acid, in addition to metabolic functions. Moreover, we confirmed the granule secretion response of Paneth cells by microinjecting butyric acid into the enteroid lumen, which suggests that Paneth cells recognize butyric acid from their apical side in the small intestine to induce $\alpha$-defensin secretion. Paneth cells expressed receptors, Gpr41 and Gpr43, which recognize butyric acid; this was confirmed by qPCR using highly purified Paneth cells and western blot analyses. Furthermore, an antagonist of Gpr41 significantly decreased butyric acid-induced granule secretion, indicating that Paneth cells recognize butyric acid via Gpr41 and secrete a-defensin in response. It is known that the butyric acid concentration in the human colon is around $12 \mathrm{o} 94 \mathrm{mM}$ and the butyric acid produced by intestinal bacteria is mostly metabolized by the colonic epithelial cells [33]. It has also been reported that GPCR is activated by SCFAs in the blood in the order of 10 to $100 \mu \mathrm{M}$ in vitro [34]; thus, $100 \mu \mathrm{M}$ to $50 \mathrm{mM}$ butyric acid used in this study may have activated the GPCRs in Paneth cells to stimulate the secretion of $\alpha$-defensin.

Amino acids are constituents of proteins, with 20 kinds existing in mammals. In this study, leucine out of 20 amino acids induced $\alpha$-defensin secretion from Paneth cells. Leucine is the most abundant essential amino acid in human tissue, and its daily requirement is the largest [35]. Leucine is known to act as signaling molecules [36] and protein synthesis in the muscle [37], in addition to materials for protein synthesis. Leucine also decreases proteasome activity on the duodenal mucosa and activates cell proliferation [38]. Moreover, it has been reported that leucine promotes insulin secretion of pancreatic $\beta$ cells and controls glucose metabolism $[39,40]$, indicating that leucine regulates diverse functions in various cells. Leucine has been reported further to activate mechanistic target of rapamycin complex 1 (mTORC1) [41]. In addition, the Paneth cell has been known to decrease mTORC1 activity by calorie restriction and enhance stem cell expansion, suggesting leucine may be involved in mTORC1 activity of Paneth cells.

In this study, we showed that Paneth cells expressed the Slc7a8 mRNA and protein, and BCH, an antagonist of Slc7a8 inhibited granule secretion induced by leucine, indicating that Paneth cells may recognize leucine via the amino acid transporter and secrete $\alpha$-defensin. Since Slc7a8 is a transporter that widely recognizes neutral amino acids, leucine may be competing for other amino acids, such as isoleucine and valine, or recognized by other receptors or transporters. Although it is not clear why only leucine induced Paneth cell secretion among amino acids, our data suggest a new function of leucine. Further studies of the signaling pathway in Paneth cell granule secretion by leucine via transporters in the intestinal environment is needed.

Paneth cells may recognize butyric acid and leucine as feeding signals and consequently secrete $\alpha$-defensin, thereby conducting surveillance in the intestine, i.e., contributing to the maintenance of intestinal homeostasis. Further and more detailed studies are needed to support this concept. In mice that have been subjected to total parenteral nutrition, Paneth cell granule numbers and reactivity to LPS are decreased compared to mice on a normal diet [42]. Furthermore, studies indicate that mice undergoing parenteral nutrition had decreased expression of Crp4, Reg III, and lysozyme mRNA in Paneth cells; these mice also had decreased Firmicutes, and increased Bacteroidetes, compared to mice fed on a normal diet [43]. Changes in the intestinal microbiota of these mice were similar to those in mice lacking the $\alpha$-defensin-activating enzyme, matrix metalloproteinase-7. Overall, total parenteral nutrition-induced state of feeding stimuli absence in the intestine is similar to a $\alpha$-defensin-deficient state; the composition of the intestinal microbiota is also similar in each state [5]. It is not likely that intestinal environmental factors, such as food and microbiota, would reach Paneth cells in the crypt bottom in a healthy state. However, food content, such as certain dietary fibers, the intestinal microbiota, and infection have been known to disrupt the mucous layer and make it thinner, so that 
nutrients can directly affect Paneth cells, as it is possible that butyric acid and leucine reach the cells $[44,45]$.

Results obtained in this study are summarized in Figure 5. Butyric acid and leucine (intestinal environmental factors), nutrients from foods, and metabolites of enterobacteria induce the secretion of $\alpha$-defensin from Paneth cells. Although BHB and BCH are not antagonists specific to Gpr 41 or Slc7a8, our results indicate that Paneth cells may recognize and respond to butyric acid and leucine via Gpr41 and Scl7a8, respectively. This study may illustrate a new role of nutrients in the maintenance of intestinal homeostasis.

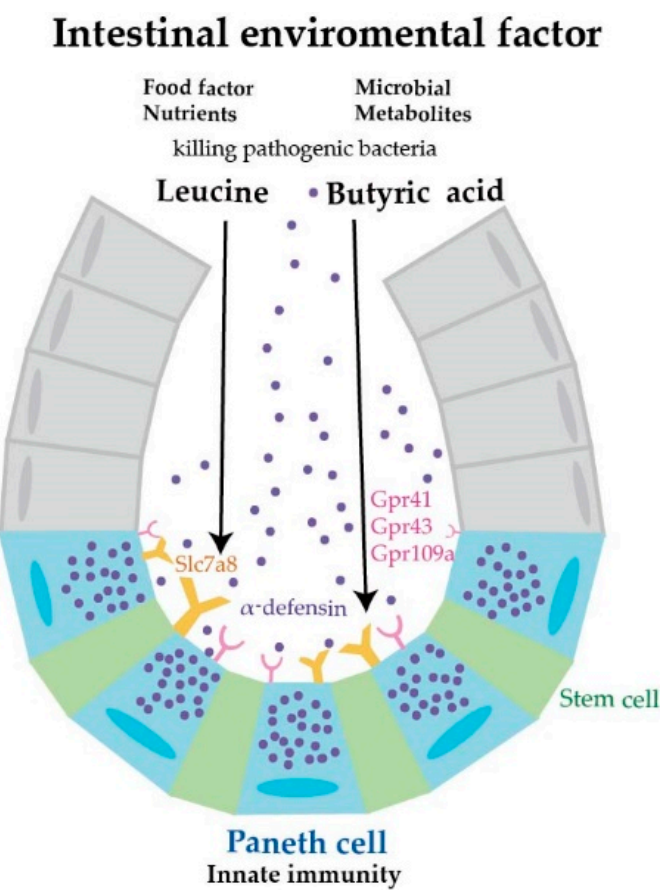

Figure 5. Paneth cell $\alpha$-defensin secretion induced by nutrients in a possible regulation of intestinal homeostasis. This study indicates that the nutrients butyric acid and leucine induce $\alpha$-defensin secretion from Paneth cells and further suggests that these nutrients perform previously unknown roles in regulating intestinal homeostasis.

Abnormalities in $\alpha$-defensin secretion are known to cause health problems and disease onset or aggravation via disruption of the intestinal environment [10]. Additionally, nucleotide-binding oligomerization domain-containing protein 2 (NOD2) mutation leads to a decrease in $\alpha$-defensin production in Paneth cells in patients with Crohn's disease [46] and the amount of immunoreactive $\alpha$-defensin decreases in obese people [47]. Furthermore, in the GVHD model mice, severe dysbiosis due to Paneth cell disappearance could be reversed by administration of Wnt agonist R-Spondin1 $[48,49]$, leading to an increase in Paneth cell numbers and recovery in $\alpha$-defensin secretion, curing dysbiosis and resulting in significantly improved disease conditions [50]. Together with accumulated evidence, our data showed that certain nutritional components of foods, i.e., intestinal environmental factors, induce $\alpha$-defensin secretion from Paneth cells, thus revealing a new role for nutrients, which may lead to the development of preventive methods or even therapeutics for disorders, such as lifestyle diseases. Overall, we identified a new direct innate immune function of the nutrients, butyric acid and leucine, which suggests that food contributes to the maintenance of intestinal homeostasis via $\alpha$-defensin secretion by Paneth cells.

Supplementary Materials: The following are available online at http://www.mdpi.com/2072-6643/11/11/2817/s1. Supplementary methods: Quantification of granule secretion by Paneth cell stimulated from the basolateral side. Table S1: Primer sequence list for qPCR. Figure S1: Induction of Paneth cell Crp1 secretion in response to $100 \mu \mathrm{M}$ Ascorbic acid. Figure S2: (a) Analysis of Paneth cell Crp1 secretion in response to 1-100 $\mu \mathrm{M}$ butyric acid. 
(b) Analysis of Paneth cell Crp1 secretion in response to $100 \mathrm{nM}-10 \mu \mathrm{M}$ leucine. Figure S3: Comparison with the granule secretion before and after by SCFA or amino acid injection. Figure S4: Quantification of granule secretion by Paneth cell stimulated from the basolateral side.

Author Contributions: A.T. developed the concept and design of the study, conducted the experiments, analyzed and interpreted data, and wrote the paper. T.A. supervised the study, conceptualized and designed the experiments, and wrote the paper. K.N. supervised the study, conducted experiments, data analysis, and interpretation. M.K., R.S., S.O. and Y.Y. conducted experiments and data analysis and interpretation.

Funding: This study was supported by grants from the Japan Society for the Promotion of Science KAKENHI Grant Number 18K17931 (to A.T.), 17K11661 (to K.N.) and 18H02788 (to T.A.), the Special Research Grant from Tenshi College (to A.T.), and the Center of Innovation Program from the Japan Science and Technology Agency, Grant Number JPMJCE1301 (to K.N. and T.A.).

Acknowledgments: We thank Aiko Kuroishi for the experimental support.

Conflicts of Interest: The authors declare no conflict of interest.

\section{References}

1. Ayabe, T.; Satchell, D.P.; Wilson, C.L.; Parks, W.C.; Selsted, M.E.; Ouellette, A.J. Secretion of microbicidal alpha-defensins by intestinal Paneth cells in response to bacteria. Nat. Immunol. 2000, 1, 113-118. [CrossRef] [PubMed]

2. Ayabe, T.; Satchell, D.P.; Pesendorfer, P.; Tanabe, H.; Wilson, C.L.; Hagen, S.J.; Ouellette, A.J. Activation of Paneth cell alpha-defensins in mouse small intestine. J. Biol. Chem. 2002, 277, 5219-5228. [CrossRef] [PubMed]

3. Selsted, M.E.; Ouellette, A.J. Mammalian defensins in the antimicrobial immune response. Nat. Immunol. 2005, 6, 551-557. [CrossRef] [PubMed]

4. Masuda, K.; Sakai, N.; Nakamura, K.; Yoshioka, S.; Ayabe, T. Bactericidal activity of mouse alpha-defensin cryptdin-4 predominantly affects noncommensal bacteria. J. Innate Immun. 2011, 3, 315-326. [CrossRef]

5. Salzman, N.H.; Hung, K.; Haribhai, D.; Chu, H.; Karlsson-Sjoberg, J.; Amir, E.; Teggatz, P.; Barman, M.; Hayward, M.; Eastwood, D.; et al. Enteric defensins are essential regulators of intestinal microbial ecology. Nat. Immunol. 2010, 11, 76-83. [CrossRef] [PubMed]

6. Mastroianni, J.R.; Ouellette, A.J. Alpha-defensins in enteric innate immunity: Functional Paneth cell alpha-defensins in mouse colonic lumen. J. Biol. Chem. 2009, 284, 27848-27856. [CrossRef]

7. Mastroianni, J.R.; Costales, J.K.; Zaksheske, J.; Selsted, M.E.; Salzman, N.H.; Ouellette, A.J. Alternative luminal activation mechanisms for Paneth cell alpha-defensins. J. Biol. Chem. 2012, 287, 11205-11212. [CrossRef]

8. Sartor, R.B. Microbial influences in inflammatory bowel diseases. Gastroenterology 2008, 134, 577-594. [CrossRef]

9. Salzman, N.H.; Bevins, C.L. Dysbiosis-A consequence of Paneth cell dysfunction. Semin. Immunol. 2013, 25, 334-341. [CrossRef]

10. Nakamura, K.; Sakuragi, N.; Takakuwa, A.; Ayabe, T. Paneth cell alpha-defensins and enteric microbiota in health and disease. Biosci. Microbiota Food Health 2016, 35, 57-67. [CrossRef]

11. Nakamura, K.; Sakuragi, N.; Ayabe, T. A monoclonal antibody-based sandwich enzyme-linked immunosorbent assay for detection of secreted alpha-defensin. Anal. Biochem. 2013, 443, 124-131. [CrossRef] [PubMed]

12. Becerril, A.; Castillo-Robles, G.; Gonzalez-Hernandez, M.; Villanueva, I. Influence of high-calorie (cafeteria) diets on the population of Paneth cells in the small intestine of the rat. Eur. J. Morphol. 2005, 42, $201-207$. [CrossRef] [PubMed]

13. Sato, T.; van Es, J.H.; Snippert, H.J.; Stange, D.E.; Vries, R.G.; van den Born, M.; Barker, N.; Shroyer, N.F.; van de Wetering, M.; Clevers, H. Paneth cells constitute the niche for Lgr5 stem cells in intestinal crypts. Nature 2011, 469, 415-418. [CrossRef] [PubMed]

14. Igarashi, M.; Guarente, L. mTORC1 and SIRT1 cooperate to foster expansion of gut adult stem cells during calorie restriction. Cell 2016, 166, 436-450. [CrossRef] [PubMed]

15. Yilmaz, O.H.; Katajisto, P.; Lamming, D.W.; Gultekin, Y.; Bauer-Rowe, K.E.; Sengupta, S.; Birsoy, K.; Dursun, A.; Yilmaz, V.O.; Selig, M.; et al. mTORC1 in the Paneth cell niche couples intestinal stem-cell function to calorie intake. Nature 2012, 486, 490-495. [CrossRef] 
16. Hara, T.; Hirasawa, A.; Ichimura, A.; Kimura, I.; Tsujimoto, G. Free Fatty Acid Receptors FFAR1 and GPR120 as Novel Therapeutic Targets for Metabolic Disorders. J. Pharm. Sci. 2011, 100, 3594-3601. [CrossRef]

17. Liu, J.; Yu, K.; Zhu, W. Amino acid sensing in the gut and its mediation in gut-brain signal transduction. Anim. Nutr. 2016, 2, 69-73. [CrossRef]

18. Yokoi, Y.; Nakamura, K.; Yoneda, T.; Kikuchi, M.; Sugimoto, R.; Shimizu, Y.; Ayabe, T. Paneth cell granule dynamics on secretory responses to bacterial stimuli in enteroids. Sci. Rep. 2019, 9, 2710. [CrossRef]

19. Kimura, I.; Inoue, D.; Maeda, T.; Hara, T.; Ichimura, A.; Miyauchi, S.; Kobayashi, M.; Hirasawa, A.; Tsujimoto, G. Short-chain fatty acids and ketones directly regulate sympathetic nervous system via $\mathrm{G}$ protein-coupled receptor 41 (GPR41). Proc. Natl. Acad. Sci. USA 2011, 108, 8030-8035. [CrossRef]

20. Kim, C.S.; Cho, S.H.; Chun, H.S.; Lee, S.Y.; Endou, H.; Kanai, Y.; Kim, D.K. BCH, an inhibitor of system L amino acid transporters, induces apoptosis in cancer cells. Biol. Pharm. Bull. 2008, 31, 1096-1100. [CrossRef]

21. Wrong, O.M. Definitions and history. In Physiological and Clinical Aspects of Short-Chain Fatty Acids, 1st ed.; Cummings, J.H., Rombeau, J.L., Sakata, T., Eds.; Cambridge University Press: Cambridge, UK, 2004; pp. 1-14. ISBN 0521440483.

22. Brown, A.J.; Goldsworthy, S.M.; Barnes, A.A.; Eilert, M.M.; Tcheang, L.; Daniels, D.; Muir, A.I.; Wigglesworth, M.J.; Kinghorn, I.; Fraser, N.J.; et al. The Orphan G protein-coupled receptors GPR41 and GPR43 are activated by propionate and other short chain carboxylic acids. J. Biol. Chem. 2003, 278, 11312-11319. [CrossRef] [PubMed]

23. Le Poul, E.; Loison, C.; Struyf, S.; Springael, J.Y.; Lannoy, V.; Decobecq, M.E.; Brezillon, S.; Dupriez, V.; Vassart, G.; Van Damme, J.; et al. Functional characterization of human receptors for short chain fatty acids and their role in polymorphonuclear cell activation. J. Biol. Chem. 2003, 278, 25481-25489. [CrossRef] [PubMed]

24. Maslowski, K.M.; Vieira, A.T.; Ng, A.; Kranich, J.; Sierro, F.; Yu, D.; Schilter, H.C.; Rolph, M.S.; Mackay, F.; Artis, D.; et al. Regulation of inflammatory responses by gut microbiota and chemoattractant receptor GPR43. Nature 2009, 461, 1282-1286. [CrossRef] [PubMed]

25. Ganapathy, V.; Thangaraju, M.; Prasad, P.D.; Martin, P.M.; Singh, N. Transporters and receptors for short-chain fatty acids as the molecular link between colonic bacteria and the host. Curr. Opin. Pharmacol. 2013, 13, 869-874. [CrossRef]

26. Kasubuchi, M.; Hasegawa, S.; Hiramatsu, T.; Ichimura, A.; Kimura, I. Dietary gut microbial metabolites, short-chain fatty acids, and host metabolic regulation. Nutrients 2015, 7, 2839-2849. [CrossRef]

27. Ohira, H.; Tsutsui, W.; Fujioka, Y. Are short chain fatty acids in gut microbiota defensive players for inflammation and atherosclerosis? J. Atheroscler. Thromb. 2017, 24, 660-672. [CrossRef]

28. Singh, N.; Gurav, A.; Sivaprakasam, S.; Brady, E.; Padia, R.; Shi, H.; Thangaraju, M.; Prasad, P.D.; Manicassamy, S.; Munn, D.H.; et al. Activation of Gpr109a, receptor for niacin and the commensal metabolite butyrate, suppresses colonic inflammation and carcinogenesis. Immunity 2014, 40, 128-139. [CrossRef]

29. Bach Knudsen, K.E.; Laerke, H.N.; Hedemann, M.S.; Nielsen, T.S.; Ingerslev, A.K.; Gundelund Nielsen, D.S.; Theil, P.K.; Purup, S.; Hald, S.; Schioldan, A.G.; et al. Impact of diet-modulated butyrate production on intestinal barrier function and inflammation. Nutrients 2018, 10, 1499. [CrossRef]

30. Furusawa, Y.; Obata, Y.; Fukuda, S.; Endo, T.A.; Nakato, G.; Takahashi, D.; Nakanishi, Y.; Uetake, C.; Kato, K.; Kato, T.; et al. Commensal microbe-derived butyrate induces the differentiation of colonic regulatory $\mathrm{T}$ cells. Nature 2013, 504, 446-450. [CrossRef]

31. Zhang, Y.G.; Wu, S.; Yi, J.; Xia, Y.; Jin, D.; Zhou, J.; Sun, J. Target intestinal microbiota to alleviate disease progression in amyotrophic lateral sclerosis. Clin. Ther. 2017, 39, 322-336. [CrossRef]

32. Sugi, Y.; Takahashi, K.; Kurihara, K.; Nakano, K.; Kobayakawa, T.; Nakata, K.; Tsuda, M.; Hanazawa, S.; Hosono, A.; Kaminogawa, S. alpha-Defensin 5 gene expression is regulated by gut microbial metabolites. Biosci. Biotechnol. Biochem. 2017, 81, 242-248. [CrossRef] [PubMed]

33. Mortensen, P.B.; Clausen, M.R. Short-chain fatty acids in the human colon: Relation to gastrointestinal health and disease. Scand. J. Gastroenterol. Suppl. 1996, 216, 132-148. [CrossRef] [PubMed]

34. Offermanns, S. Free fatty acid (FFA) and hydroxy carboxylic acid (HCA) receptors. Annu. Rev. Pharmacol. Toxicol. 2014, 54, 407-434. [CrossRef] [PubMed]

35. Joint WHO/FAO/UNU Expert Consultation. Protein and Amino Acid Requirements in Human Nutrition; World Health Organ Technical Report Series; WHO: Geneva, Switzerland, 2007; Volume 935, pp. 1-265. 
36. Marc Rhoads, J.; Wu, G. Glutamine, arginine, and leucine signaling in the intestine. Amino Acids 2009, 37, 111-122. [CrossRef] [PubMed]

37. Anthony, J.C.; Yoshizawa, F.; Anthony, T.G.; Vary, T.C.; Jefferson, L.S.; Kimball, S.R. Leucine stimulates translation initiation in skeletal muscle of postabsorptive rats via a rapamycin-sensitive pathway. J. Nutr. 2000, 130, 2413-2419. [CrossRef] [PubMed]

38. Coëffier, M.; Claeyssens, S.; Bensifi, M.; Lecleire, S.; Boukhettala, N.; Maurer, B.; Donnadieu, N.; Lavoinne, A.; Cailleux, A.-F.; Déchelotte, P. Influence of leucine on protein metabolism, phosphokinase expression, and cell proliferation in human duodenum. Am. J. Clin. Nutr. 2011, 93, 1255-1262. [CrossRef]

39. Sener, A.; Malaisse, W.J. The stimulus-secretion coupling of amino acid-induced insulin release: Insulinotropic action of branched-chain amino acids at physiological concentrations of glucose and glutamine. Eur. J. Clin. Investig. 1981, 11, 455-460. [CrossRef]

40. Liu, Y.J.; Cheng, H.; Drought, H.; MacDonald, M.J.; Sharp, G.W.; Straub, S.G. Activation of the KATP channel-independent signaling pathway by the nonhydrolyzable analog of leucine, BCH. Am. J. Physiol. Endocrinol. Metab. 2003, 285, E380-E389. [CrossRef]

41. Wolfson, R.L.; Chantranupong, L.; Saxton, R.A.; Shen, K.; Scaria, S.M.; Cantor, J.R.; Sabatini, D.M. Sestrin2 is a leucine sensor for the mTORC1 pathway. Science 2016, 351, 43-48. [CrossRef]

42. Omata, J.; Pierre, J.F.; Heneghan, A.F.; Tsao, F.H.; Sano, Y.; Jonker, M.A.; Kudsk, K.A. Parenteral nutrition suppresses the bactericidal response of the small intestine. Surgery 2013, 153, 17-24. [CrossRef]

43. Heneghan, A.F.; Pierre, J.F.; Tandee, K.; Shanmuganayagam, D.; Wang, X.; Reed, J.D.; Steele, J.L.; Kudsk, K.A. Parenteral nutrition decreases paneth cell function and intestinal bactericidal activity while increasing susceptibility to bacterial enteroinvasion. JPEN J. Parenter. Enteral. Nutr. 2014, 38, 817-824. [CrossRef] [PubMed]

44. Derrien, M.; Vaughan, E.E.; Plugge, C.M.; de Vos, W.M. Akkermansia muciniphila gen. nov., sp. nov., a human intestinal mucin-degrading bacterium. Int. J. Syst. Evolut. Microbiol. 2004, 54, 1469-1476. [CrossRef] [PubMed]

45. Everard, A.; Belzer, C.; Geurts, L.; Ouwerkerk, J.P.; Druart, C.; Bindels, L.B.; Guiot, Y.; Derrien, M.; Muccioli, G.G.; Delzenne, N.M.; et al. Cross-talk between Akkermansia muciniphila and intestinal epithelium controls diet-induced obesity. Proc. Nat. Acad. Sci. USA 2013, 110, 9066-9071. [CrossRef] [PubMed]

46. Tan, G.; Zeng, B.; Zhi, F.C. Regulation of human enteric alpha-defensins by NOD2 in the Paneth cell lineage. Eur. J. Cell Biol. 2015, 94, 60-66. [CrossRef]

47. Hodin, C.M.; Verdam, F.J.; Grootjans, J.; Rensen, S.S.; Verheyen, F.K.; Dejong, C.H.; Buurman, W.A.; Greve, J.W.; Lenaerts, K. Reduced Paneth cell antimicrobial protein levels correlate with activation of the unfolded protein response in the gut of obese individuals. J. Pathol. 2011, 225, 276-284. [CrossRef]

48. Eriguchi, Y.; Takashima, S.; Oka, H.; Shimoji, S.; Nakamura, K.; Uryu, H.; Shimoda, S.; Iwasaki, H.; Shimono, N.; Ayabe, T.; et al. Graft-versus-host disease disrupts intestinal microbial ecology by inhibiting Paneth cell production of alpha-defensins. Blood 2012, 120, 223-231. [CrossRef]

49. Eriguchi, Y.; Nakamura, K.; Hashimoto, D.; Shimoda, S.; Shimono, N.; Akashi, K.; Ayabe, T.; Teshima, T. Decreased secretion of Paneth cell alpha-defensins in graft-versus-host disease. Transpl. Infect. Dis. 2015, 17, 702-706. [CrossRef]

50. Hayase, E.; Hashimoto, D.; Nakamura, K.; Noizat, C.; Ogasawara, R.; Takahashi, S.; Ohigashi, H.; Yokoi, Y.; Sugimoto, R.; Matsuoka, S.; et al. R-Spondin1 expands Paneth cells and prevents dysbiosis induced by graft-versus-host disease. J. Exp. Med. 2017, 214, 3507-3518. [CrossRef]

(C) 2019 by the authors. Licensee MDPI, Basel, Switzerland. This article is an open access article distributed under the terms and conditions of the Creative Commons Attribution (CC BY) license (http://creativecommons.org/licenses/by/4.0/). 